\title{
Performance of Integrated Systems of Automated Roller Shade Systems and Daylight Responsive Dimming Systems
}

\author{
Byoung-Chul Park, Sejong University \\ An-Seop Choi, Sejong University \\ Jae-Weon Jeong, Sejong University \\ Eleanor Lee, Lawrence Berkeley National Laboratory
}

October 2010 


\section{DISCLAIMER}

This document was prepared as an account of work sponsored by the United States Government. While this document is believed to contain correct information, neither the United States Government nor any agency thereof, nor The Regents of the University of California, nor any of their employees, makes any warranty, express or implied, or assumes any legal responsibility for the accuracy, completeness, or usefulness of any information, apparatus, product, or process disclosed, or represents that its use would not infringe privately owned rights. Reference herein to any specific commercial product, process, or service by its trade name, trademark, manufacturer, or ofherwise, does not necessarily constitute or imply its endorsement, recommendation, or favoring by the United States Government or any agency thereof, or The Regents of the University of Catifornia. The views and opinions of authors expressed herein do not necessarily state or reflect those of the United States Government or any agency thereof or The Regents of the University of California. 


\title{
Performance of Integrated Systems: Automated Roller Shade Systems and Daylight Responsive Dimming Systems
}

\author{
Byoung-Chul Park ", An-Seop Choi ${ }^{\text {** }}$, Jae-Weon Jeong ${ }^{\text {a }}$, Eleanor S. Lee ${ }^{b}$

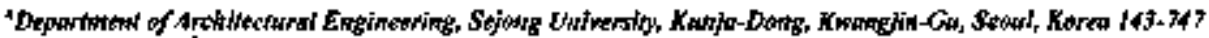

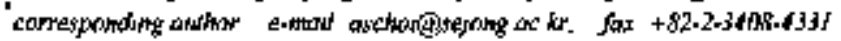

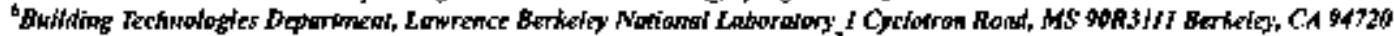

\begin{abstract}
Abstroct
Daylight responsive dimming systems have been used in few buildings to date because they require improvemetts to improve reliability. The key underlying factor contributing to poor performatice is the yariability of the ratio of the photosensor signal to daylight workplane illuminance in accordance with sun position, sky condition, and fenestration condition. Thereforc, this paper describes the integrated systems between automated roller shade systems and daylight responsive dimming systems with an improved closedloos proportional control algorithm, and the relative performance of the integrated systems and single syslems. The concept of the improved closed-lonp projortional control algorithm for the integrated systems is to predict the varying comrelation of pholosenser signal to daylight workplunt illuninume according to roller shade height and sky conditions for improvement of the system accuracy. In this study, the performance of the integrated systems with two improved closed-loop propottional control algarithrths was campared with that of the current (modified) closed-loop proportional control algorithm, In the resulis, the average maintenance percentage and the average discrepancies of the target illuminance, as well as the average lime under $90 \%$ of target illuminance for the integrated systems significantly improved in comparison with the current closed-Ionp proportional conirol algriihm for daylight responsive dimming systems as a single system.
\end{abstract}

Keywords Integrated systems, automated roller shade systems, daylight respensive dlmming systems, daylighting, photoehectric controls.

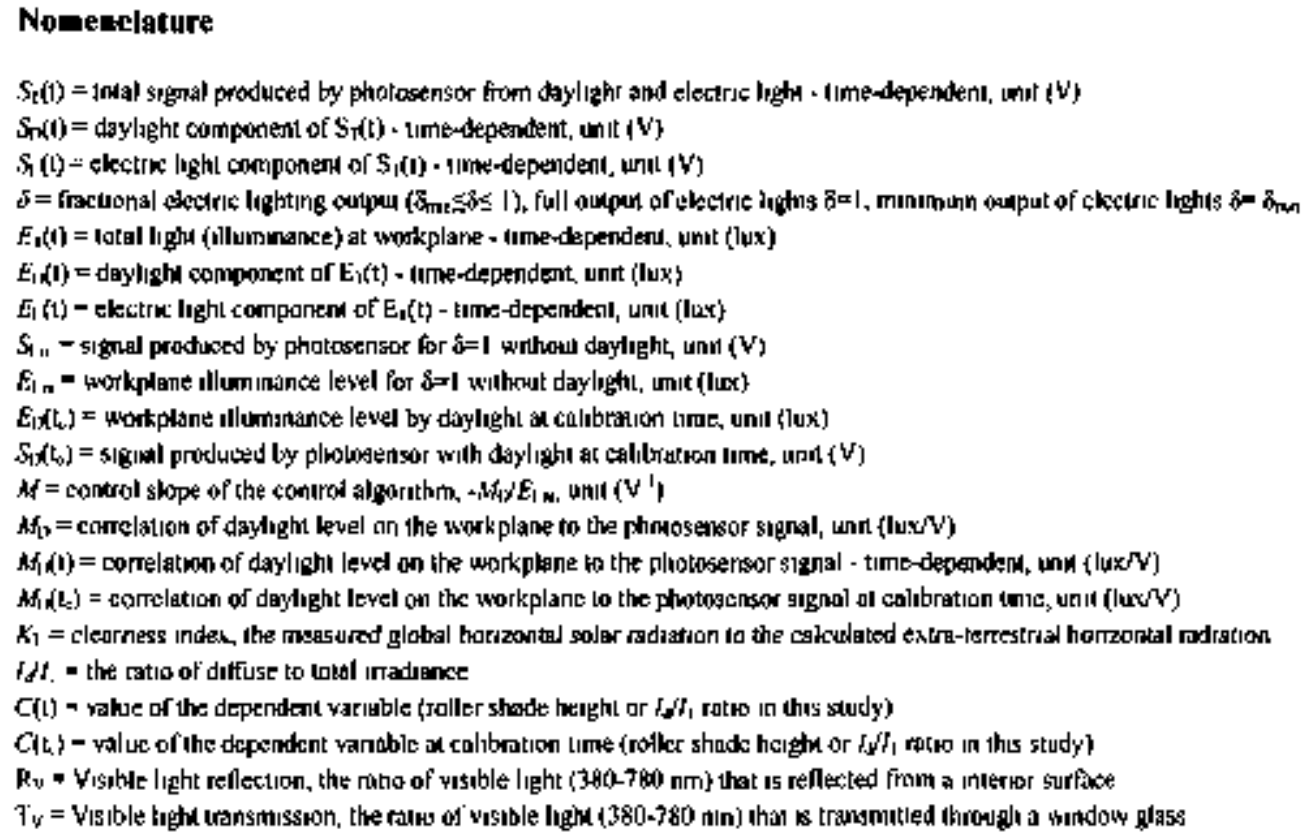




\section{InI roduction}

Daylight responsive dimming systems have immense potential to significantly reduce energy consumption in buildings, especially high-rise bulluings with glass turtain walls. Such systems can save $16-70 \%$ of cutrent anrual clectric lighting consumption, according to past ficld measurements and simulatious [ $1-4]$.

Despite thejr significant technical potential, daylight responsive dimming systems have been used in few buildings to dale hecause they require improvements to improve reliability. The key underlying factor contributing to poor per[urmance (thul is, underlit spaces) is the vuriability of $M_{\mathrm{T}}$ (the ratio ur the photosensor signal to daylight workplane illuminance) in accordance with șun position, sky conditions, and femestration conditions. When the system is commissioned under a given arbitrary sun position, sky condition, and fenestration condition, this $M_{\mathrm{D}}$ in the current control algorithm is set to a fixed value, which results in the design illuminance heing undershot under other solar and fenestration conditions.

For daylight responsive dimming systems to be able to capilalize on the uvailatle daylight, shading systems are needed to block direct sunlight and introduce available daylight without causing a discom fort glare to occupanis. Although $N_{0}$ varies according to shading system conditions, such as diflerent venetian blind angles and roller shade hejghts, the current control algorithm uses a fixed $M_{\mathrm{D}}$ al daytime calibration. $M_{\mathrm{D}}$ varies as according to sky conditions as well. Therefore, the variation of $M_{0}$ with sky and stading system conditions should be considered in destgning the control ulgorithm of daylight responsive dimming systems. Hence, daylight responsive dimming systems should be integrated wilth aulomated shoding syslems to predict varying $M_{\mathrm{b}}$ according to shading system conditions, and the control algorithm tor the integrated systems should consider varying $M_{\mathrm{D}}$ with shading syslem conditions as well as with sky conditions for the system pertonmance.

\section{Background}

Currently in general use is a modified closed-loop proportional control algorithm hased on the conventional closed-loop proportional control algorithm, in which $M_{0}$ and $E_{E n 1}$ (maximum electric workplante illuminance). are used to cakulate $\boldsymbol{N}$ (contro] slope) for the delermination of dimming level in daylight responsive dimming systems. Alıhough the degradation of $E_{\mathrm{Fm}}$ was solved using uuto-calibration (self-commissioning), vнrying $\boldsymbol{M}_{\mathrm{D}}$ with sky condirions and ferestration conditions has not been solved.

Auto-calibration of the extent to which degradalion of lamps or ballast are degrading is importanu in achieving system accuracy [5-6]. The artificial lighting illuminance on the workplane at maximum lighting output is generality estabisted at the design level, and the workplane iltuminance value with the maximum electric lighting pawer ac night-time calibralion is used to determine $M$ in the system control algorithm.

To maintain slable $M_{\mathrm{D}}$ jn daylight responsive dimming systems, researchers have establishhed an appropriale photosenswr configutation and pusition [7-12]. I.ikewise, in order to determine the appropriate $M_{D}$ at daytime calibration for calculaling $M$ in the system algorithm, appropriate calibration times and sky conditions were examined [3-14], and cormmissioning guidelines presertied [1]. Although lhese studies presenied results perlaining to optimum scusor locations, sensor-shielding designs, sensor aiming, and calibration times, the $M_{\mathrm{D}}$ varies aceotding to yarying solar and lenestration conditions. Choi and Mistrick (I998) recommended frequent (monthly) commissioning: however, this is difticult in practice because of the costs associaled with calibration and the inconverience caused to wolking occupans [ 15$]$ ].

Direct sunlight is responsible for at licost twio unwented eftects; (1) discomfort glare to oectupants, and (2) increased cooling lads in a space due to the solar and thermal loads from the windows. To block direct sunlight, windows require shading. especially in tigh-rise buildings with glass curtain walls. Roller shade systems and venetian blinds are popular for this putpose, and aulomated systems of these kinds are widely used. Aulomated roller stude systems are generally preferred over venetian blinds in higli-rise trui|dings becauje the former adjusts easily to produce the appropriale shading conditions. It should also be noted that although veretian blinds must be conirolled according to their height and slat angle, roller shade systems can be easily conirolled based on height only.

For daylight responsive dimming systems to be able to capitalize on the available daylight, shiding systems such as roller shades are needed to block direct sunlight and introduce available daylight without causing a discomfort glare to occupants. To illustrate, the building where The hew Yonth Fimes is headquartered has both daylight responsiye dimming systems and aulonated coller shade systems installed [4, |6]; however, the 
systems operate separately. Any change to the shading system conditions affects the daylight distribution in a space; thus, the resulting change in the daylight distribution, llake the varying $H_{0}$ in daylight responsive dimming systems, can inipail the accuracy of the daylight responsive dimming system. To improve the performance of daylight responsive dimming systems as well as the autormated roller shade systems, the two systems should bo integraled and provided with an improved control algorithm.

This study hypothesized that wo factors alfect variation of,$F_{0-}$ The hypothesis is that the variation of $M_{0}$ is slatistically influenced by variations in sky condition and roller shade height (independent variables: sky condition and roller shade heights: dependant variable: $M_{\mathrm{D}}$, and the varying $M_{\mathrm{D}}$ can be predicled using the indeperiden variable.

To examine the hypothesis for this study, two solstice-to-solstice field experiments were conducted in a tullscule model and a half-scale model of typically daỵlighted spaces but in different louations, and the Jata Jor workplane illuminance, photosensor signals, exterior horizontal jeradiance, and roller shaded hejghts were measured. The first experiment used the full-scalc tesibed to investigate varying $w_{0}$ and its trend according io sky condition and roller shade height. The second experiment ușed the half-şcalle model in order to provide a basis upon which to validale the results from the firs experionent.

The gouls of the work described herein are to integrale daylight respernsive dimming systems wijh automaled roller shade systems, to present the control algorithm used in this integrated systems, and to compare the integrated system performance to the single system periormante. The $M_{0}(t)$ (time-dependenl $\left.M_{0}\right)$ was characterized in tem of roller shade theights and sky conditions at each of the differenl roller shade heights. 1'his type of characterizalion can be integrated into a control algorithon to predico the varying $M_{n}(0)$, and automated rolletr sthade systems can be integrated with daylight responsive dimning systems as integrated systems. Therefiore, inlegrated systems with a conirol algotithm uycre presented and cyaluated in this specific case stuwdy.

\section{Methód}

\section{3./ Test facility and conditions}

The Windows Testbed Facility with three identical test rooms was located at the Laurence Berkeley National Labotatory in Berkeley. California (latitude $37^{\prime \prime} 4^{\prime} \mathrm{N}$, ]ongitude $122^{\prime} \mathrm{g}$ 'W'). Fach of the three identical side-byside furnished test moms was $3.05 \mathrm{~m}$ wide by $4.57 \mathrm{ml}$ deep by $3.35 \mathrm{~m}$ high and each had a $3.05 \mathrm{~m}$ wide by 3.35 m high window wall facing south. A single, interior, lop-down roller shade (light-gray basketweave, 3\% openness tactor) was cycled for 5 -minute intervals, each with different roller shade height (6 steps: $0,0.2,0.4$, $0.6,0.8$, and 1 of roller shade height ratio; the controlled roller shade height to the maximum window height) in a test roon. Only the test room data among the three lest rooms was used for this siudy.

Although the system was automatically dimmed during the monitored period for a parallel test objective, the actual iighting 5ystem was not significant. The clectric Jighting value on the workplane was extrasted using the derived quadratic fit between power use and electric lighting workplanc illuminance from night-time measured data, so that the analysis was only conducted on daylight illumimance. The fit had a 5.13 lux average KMSE (Root Mean Square Ersor) in a 201- I010\% dimming range.

The test rooms were monilorad over a sjx-month, solstice-to-solstive period from Devimber 21, 2007, to June 21, 20618. The illuminance. phorosensor voluge, and exterior horizontal iradiance data were sampled and recorded at 5 -min intervals over a 24 h perjod using the LabView Nalional Insiruments data açuisition suliware. ] the lest room configuration The six wrokplane illuminance sensars al $0.76 \mathrm{~m}$ facing toward the ceiling were manicored using a culur and cosine-corrected silicone diude photumetric sensor (L1-210SA, $\pm 1.5 \% 107500$ lux, $\pm 0.15 \%$ PC maximum). However, only the average illuninance from the four rear workplane sensors was related to the photosensor signal (Fig. l): this was hecause only thest sensors were within the photosensor's direct field of vicw.

The PS-eeil of a shielded pholosensor (Perkin Elmer VT5031B, 0.02\%/ C) was placed an the south end of the second light fixture, $2.73 \mathrm{~m}$ lrom the window wall and flush wijth the bottom of the fixture, $2.54 \mathrm{~m}$ above the finished fioor. The PS-ceil had a $60^{\circ}$ cone of view and was pointed downugrd normal to the fioor. Ihs view was defined as a circular area on the floor with a sadius of $1.47 \mathrm{~m}$. 

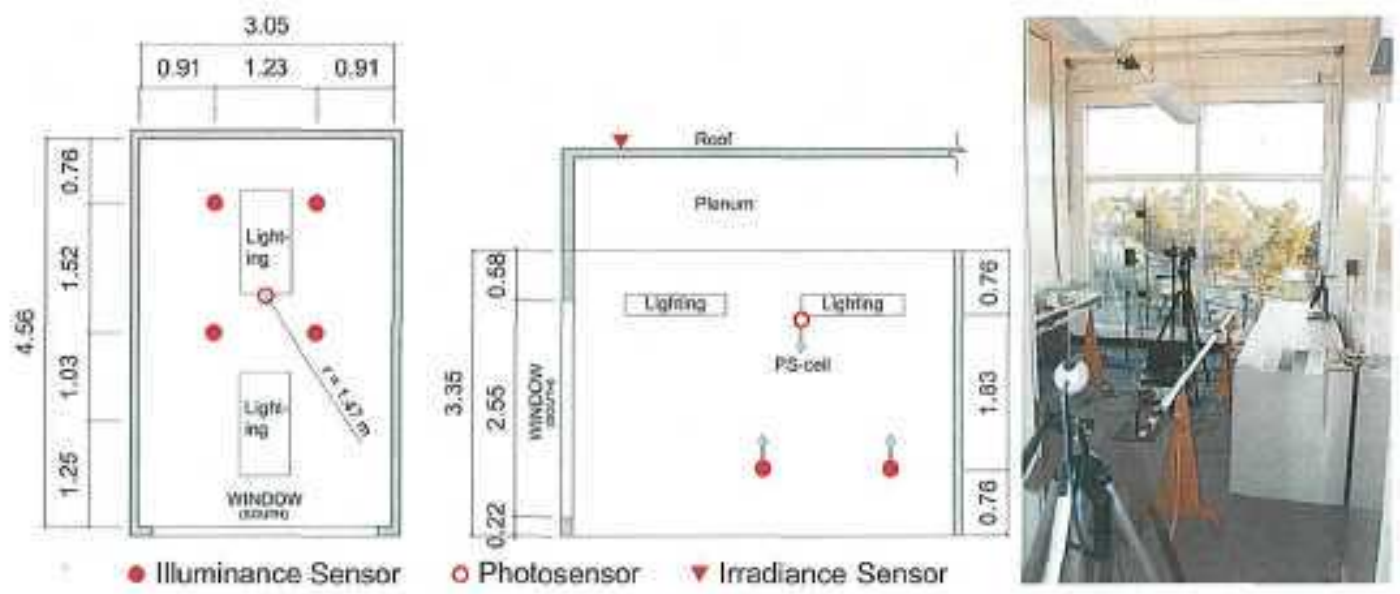

Fig. I. Floor plan and section for the sensors' positions, and interior view of the test room for the full-scale testbed, Dimensions are given in meters.

An exterior horizontal irradiance sensor ( $\mathrm{Ll}-200 \mathrm{SA}, \pm 1.0 \%$ to $3000 \mathrm{~W} / \mathrm{m}^{2}, \pm 0.15 \% /{ }^{\circ} \mathrm{C}$ ) was located on the roof of the testbed. The data was used to calculate $K_{\mathrm{T}}$ (clearness index; the measured global horizontal solar radiation to the calculated extra-terrestrial horizontal radiation) and $I_{\mathrm{d}} / I_{\mathrm{T}}$ (the ratio of diffuse to total irradiance) for classification of sky conditions. A more detailed description of the experimental setup can be found in the study by Lee et al. [17].

To verify the trends of the test results in this study, the data were monitored in a half scale mock-up test room at Sejong University, Seoul, Korea (latitude $37^{\prime} 33^{\prime} \mathrm{N}$, longitude $127^{\circ} 04^{\prime} \mathrm{E}$ ) (Fig. 2). Each unfurnished test room was $1.51 \mathrm{~m}$ wide by $2.87 \mathrm{~m}$ deep by $1.57-1.64 \mathrm{~m}$ high (inclined roof) and had a $1.22 \mathrm{~m}$ wide by $1.29 \mathrm{~m}$ high window facing due south. Each room had a single window, which were simultaneously exposed to approximately the same interior and exterior environment. A single, top-down, 3\%-open, light-gray (both side) basketweave fiberglass/PVC fabric roller shade was installed in one of the three test rooms. The testbed facility description and roller shade control method in detail are shown in the conference paper by Park and Choi [18].


Fig. 2. Floor plan and section for the sensors' positions, and interior view of the test room for the half-scale testbed. Dimensions are given in meters.

\subsection{Analysis}

Some of the monitored data were eliminated from the datasets used for analysis. Specifically, the following data were climinated: for 1-min data before and after the roller shade height was changed, the data after sunset within a $10 \mathrm{~h}$ period, 8:00 a.m.-18:00 p.m., and the data of the exceeded maximum photosensor signal (>10 V).

The monitored data of cycled roller shade height in the full-scale testbed were analyzed to establish correlations between varying $M_{\mathrm{D}}(\mathrm{t})$ and roller shade heights and sky conditions. $I_{d} I_{\mathrm{T}}$ ratio was used as a classification of solar conditions, and this independent variable was used in the analysis of the varying $M_{\mathrm{D}}$ data. The $I_{d} / I_{\mathrm{T}}$ ratio was calculated using the calculated $K_{\mathrm{T}}$ and $I_{\mathrm{d}} / I_{\mathrm{T}}$-versus- $K_{\mathrm{T}}$ correlation by Erbs $e t$ al. $(1982)$, and the $K_{\mathrm{T}}$ values were calculated using the measured global horizontal solar radiation and the calculated extra-terrestrial horizontal radiation [19]. The data for twenty-one days over six-months were analyzed in this study (Table 1). 
Tuble I

Dale of the monitrred dala used for analysis.

\begin{tabular}{|c|c|c|c|c|c|c|}
\hline Jant & Fisb & Mar & $\mathrm{Apr}$ & Mtry & Jun & Sum of Days \\
\hline 7,8 & 7,8 & $7-9,22-24$ & $6,21-23$ & $10-12 ; 25-27$ & 10 & 21 \\
\hline
\end{tabular}

\section{Integrated control algorithm with modified closed-Haop proportional contrinl algarithm}

In this study, the slope of the linear correlation between the photosensor signal and the average daylight workplane illuminance, $w_{0}$, was assumed to be adjustab]e independent wariable trom the slope of the correlation between the photosensor signal and the average electric lighting workplane illuminance, $w_{\mathrm{E}}$. With conventional control systems, these two slopes are adjusted simulteneously and ane, therctore, interdependent, theneby leading to poor performance. In the study by Lee et al. (1998), the two slopes were set independently and $M_{\mathrm{D}}$ was yaried as a function of the venetian blinds' stat angle for an autonated prototypical venetian bjind-lighting control 5ysiem [1].

The concept of the modificd closed-loop proportional control algorithm is to adjust the clectric light level as a linear function of the dilference between $S_{\mathbf{r}}(t)$ (total pholosensor signal from daylight and electric light) and $S_{\mathrm{E}}(\mathbf{t})$ (electric component of $S_{\mathrm{T}}(\mathrm{t})$ ) as given by:

$\delta=M\left(S_{\gamma}(t)-S_{t}(t)\right)+1, M<0$

The equation of $M$ in the modified closed-loop proportional control algorithm can be derived with $M_{0}\left(I_{4}\right)$ as in eq. 2 , where $t$ is the single time of calibration:

$M\left(t_{\mathrm{r}}\right)=\frac{-M_{t s}\left(t_{\mathrm{c}}\right)}{E_{\text {lik }}}$

We assumed that if the cotrelations of the varying $M_{0}(t)$ to the changed parameters (coller shade height and sky conditions) are directly proportional, $\mathrm{H}_{\mathrm{r}}(t)$ can twe predicled from at least two daytime calibrations at low' and high conditions of the changed paramelers. $M$ in the modified elostd-loop proportional control algorithm can bs continuously adjusted via software as a function of the actual data of roller starde height and a $f_{\mathrm{d}} / t_{\mathrm{T}}$ ralio.

$M_{\mathrm{b}}(\mathrm{l})$ can be changed with $M_{\mathrm{D}}(\mathrm{t})$ to predicl the varyigg $M_{\mathrm{D}}$, and $M_{\mathrm{D}}(\mathrm{t})$ can be moditied with Newton's intergolation formula For two calibralions, as showt in eq. 3. II was assumed that the dfuided conditions of the coller shade height or the $l_{d} / t_{\mathrm{T}}$ ratio for the two calibrations would be expressed as $C\left(\mathrm{~L}_{\mathrm{c}}\right)$ and $C\left(\mathrm{t}_{\mathrm{c}}\right)$ :

$$
M_{b}(t)=\frac{M_{b}\left(t_{c 1}\right)-M_{b}\left(t_{c 2}\right)}{C\left(t_{c 1}\right)-C\left(t_{c 2}\right)}\left(C(t)-C\left(t_{t-1}\right)\right)+M_{b}\left(t_{c 1}\right)
$$

In this study, the pertormance of the integraled syslems, each of which used one of the two improved closed. loop propurtional control algorithms using these equations (i-3), one using only the roller shade height and the nther using the $I_{d} t_{r}$ ratio al different roller shade heights, was evalualed to compare the modified closed-lonp proportional contrul algoriam in daylight responsive dimoning syslems as a single system.

\section{Results}

[o illustrate how $h_{0}(t)$ varies, two parameters - the roller shade height and the $f_{d} / t_{T}$ ratio - were tracked on March 22, 2008 (Fig- 3). The varying $M_{\mathrm{b}}$ fluclualed signilicantly according to the cycled roller shude height, and $M_{0}$ was also arrected by changes in the $d_{d} / t_{\mathrm{r}}$ ratio. 




Fig. 3. Trend resulting from varying $M_{\mathrm{D}}$ by roller shade height and $l_{\mathrm{d}} / l_{\mathrm{T}}$ on March 22, 2008.

\section{$5.1 M_{B}$ vs. roller shade heights}

How $M_{\mathrm{D}}(\mathrm{t})$ varies with regard to each roller shade height as a linear relationship using the valid monitored data was examined. The variation of $M_{b}(t)$ with regard to roller shade height showed that the value of $M_{\mathrm{D}}(t)$ decreased proportionally for a roller shade height ratio form 0 to 0.4 , and increased proportionally for a roller shade height ratio form 0.4 to 1 . The $M_{\mathrm{D}}(t)$ data to roller shade height for the test period were divided into two ranges, $0-0.4$ and $0.4-1.0$ ratios of the roller shade height, and derived as two separate linear relationships, where the $\mathrm{R}^{2}$ values of the correlations were 0.5838 and 0.5770 , respectively (Fig. 4 ). The results indicate that calibrations performed at $0,0.4$, and 1.0 ratios of the roller shade height can be considered. Although $58 \%$ reliability is not high, the deviation of the predicted $M_{\mathrm{b}}(t)$ using these correlations will significantly decrease.

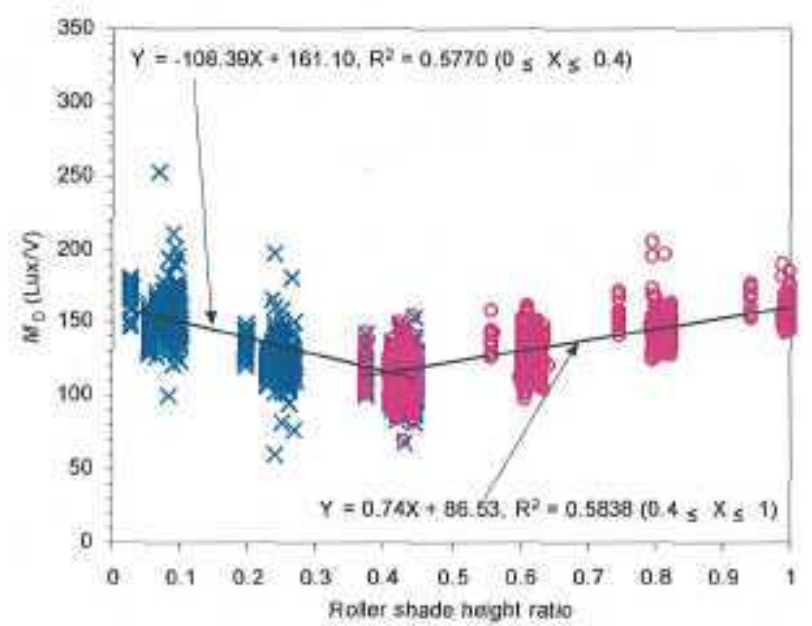

Fig. 4. Linear relationships of $M_{\mathrm{D}}$ to roller shade height in two separate ranges.

\section{$5.2 M_{B}$ vs. $I_{A} I_{r}$ at the cycled roller shade heights}

For each given fixed roller shade height, $M_{\mathrm{D}}$ varies with the $I_{\mathrm{d}} / I_{\mathrm{T}}$ of sky conditions (Fig. 5). The $I_{\mathrm{d}} / I_{\mathrm{T}}(\mathrm{t}=2.17, p$ $<0.05$ ) at 0.0 of the ratio of the controlled roller shade height to the maximum window height contributed to the varying $M_{\mathrm{D}}$; however, the $\mathrm{R}^{2}$ of the linear fit at 0.0 of the ratio of the controlled roller shade height to the maximum window height was also almost zero $\left(\mathrm{R}^{2}=0.0095\right)$. So, the $I_{\mathrm{d}} / I_{\mathrm{T}}$ can be ignored at 0.0 of the controlled roller shade height. The $\mathrm{R}^{2}$ of the linear fit at $0.2,0.4,0.6,0.8$, and 1.0 of the ratio of the controlled roller shade height to the maximum roller shade height were $0.2781,0.6363,0.4865,0.3513$, and 0.2120 in $p<0.01$. respectively. 



Fig. 5. Linear relationships of $M_{\mathrm{D}}$ to $I_{\mathrm{d}} / I_{\mathrm{T}}$ at different roller shade heights ( $1=$ overcast).

When direct sunlight penetrates into a space on the workplane, the roller shade should be down in order to block direct sunlight from the workplane. Therefore, more than 0.6 ratio $(60 \%)$ of the roller shade height should be used without discomfort glare, such as in the overcast sky condition. Although the roller shade's main function is to block direct sunlight, the automated roller shade system when integrated with a daylight responsive dimming system should be controlled so as to introduce available daylight without discomfort glare. 


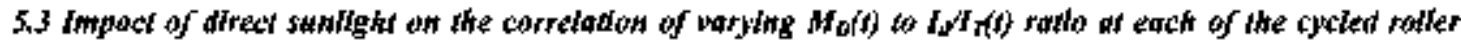 shade heights}

To analyze the effects of direct sunight on the comeration of varying $M_{\mathrm{D}}(t)$ to the $d_{0} / t_{\mathrm{T}}(t)$ ratio at each of the cycled ruller shade heighls, the dataset was slassified according to whether direcl sunlight interfered or did not interfere with the detection area of the PS-ceil on the floor. A sun profile angle was used to calculate the penctration distance to the PS-ceil detection area.

The total data and two divided dala were compared based on a linear relationshij) of $W_{0}(t)$ to $d_{d} / f_{T}(t)$ (Table 2 ). The $\mathbf{R}^{2}$ of the derived fil of $M_{\mathrm{D}}(1)$ lo $\sigma_{\mathrm{T}}\left(t_{\mathrm{T}}(\mathrm{t})\right.$ was increased wilh a small gap when the interfering data in the PSceil delevtion area wert excluded. Occupunts tend to slose roller shades when Jirest sunlight jnlerleres with their desks or when djscomforl glare occurs. Therefore, to render reliable the linçar relationship of $M_{0}(1)$ to $f_{4} / f_{\mathrm{T}}(\mathrm{t})$ in the improved closed-loop proportional control systems. direct sunlight must be blocked withoul a perimeter zone, and the roller shade height should be controlled wilhoul interference by direct sunlight in the detection area of the photosensor.

Table 2

Linear retationship of $M_{0}$ to $t_{d} / t_{T}$ at differenl roller shade heights as expressed by the divided dala with and without interterence of the HS-ceil detecting area.

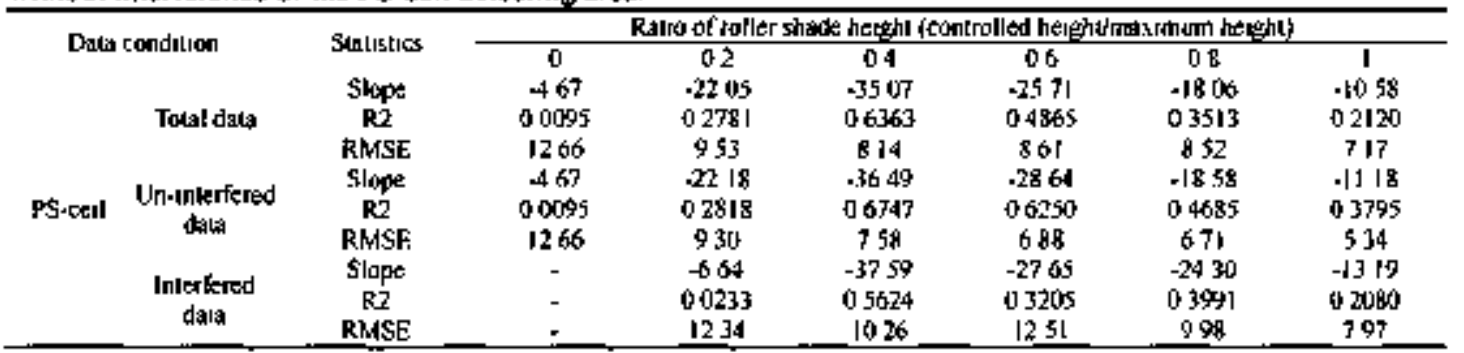

5.4 Pefformunce of the integrated systems with ench improved clased-foop proportionnt control algorithm

The perlormance of the integtated sysiems each of which used ont of the two improved closed-lowp proportional control algorithms - onc ussing only roller shade hejght and the other using the $t_{d} / t_{1}$ ratio at diflerent roller shade heights - was evalualed to compare the modified clased-loop proportional control algorithm in daylight responsive dimming systems as a single system. Firsly, only the roller shade height as an independent variable for predicting varying $M_{0}$ was integtated into the improved closed-loop proportional control algorithm for the integrated 5ystems. In this case, the $f_{d} / t_{\mathrm{T}}$ tatio was ignored for the simple $5 y$ stem with no added component for the integrated systems. To consider the $t_{d} / T_{\mathrm{J}}$ ratio for the inlegrated systems, a horizonial global exlerior jrradjance sensor should be used to calculate the $t_{d} / t_{T}$ raljo, and this added componen! increases the initial costs. Secondly, the $f_{d} t_{T}$ ratio al different roller shade heights as an independent variable for predicting varying $W_{0}$ was jntegtated into the improved closed-loop proportional control algorithm to improve system accuracy. Although the second improved closed-loop proportional control systen could be further improves by diverse and trequent salibrations, the initial cost of doing so would inctease becaluse the latter would entail measuring the exterior glotal irradiance on the horizontal surface.

The integrated systems, each of which used one of the improved closed-1oop proportinnal control algorithms, were compared with the daylight responsive dimming systems, whlch used the current closed-loop proportlonal control algorithm (modificd closed-10op proportional conirol algorithm) using monitored data for the 8:00 a.m.18:00 p.m. period over 21 days. The integrated systems were separated based on two cothditionsi roller shade height and the $i_{\mathrm{d}} / t_{\mathrm{T}}$ raljo al different roller shade heights. The electric component of the workplant illuminance was calculated from the $\delta$ determined by $M_{0}$ in each control algorithm, and added to the measured daylight component in order to derive the total workplente illuminance.

To calculate if for the turrent daylight responsive dimming systems, a single daytimt-calibration is generally performed when the sky condision is not partly clondy and there is no direct sunlight in the room [1]. In this


with the inuproved closed.|oop proportional control algorithm using only the coller shade height, three calibations at $0,0.4$, and $]$ of the ratio of the contiolled rallel' shaded height to its maximum for eath linear relalionship $0-0.4$ and $0.4-1$ of the ratio were adopied. For the integrated systenis, with the improved closed. 
loop proportional control algorithm using the $t_{d} / t_{\mathrm{T}}$ tatio at different coller shude heights, a single culibratfon at 0 of the roller shade height ratio was adopted, and each of the two calibrations al $0.2,0.4,0.6$, 0.8 , and 1.0 of the ralio was adopted. Each of the toller shade heights for the calibrations was a representative value for each of the roller shade height range. Each calibration dataget was collected at around I5:00 PM on April 21 and 22, 2008, and the conditions atd conditional expressions are shown in Table 3.

Table 3

Conditions al calibrations for each of the control algorithms and the derived functions of $M$ and $n$.

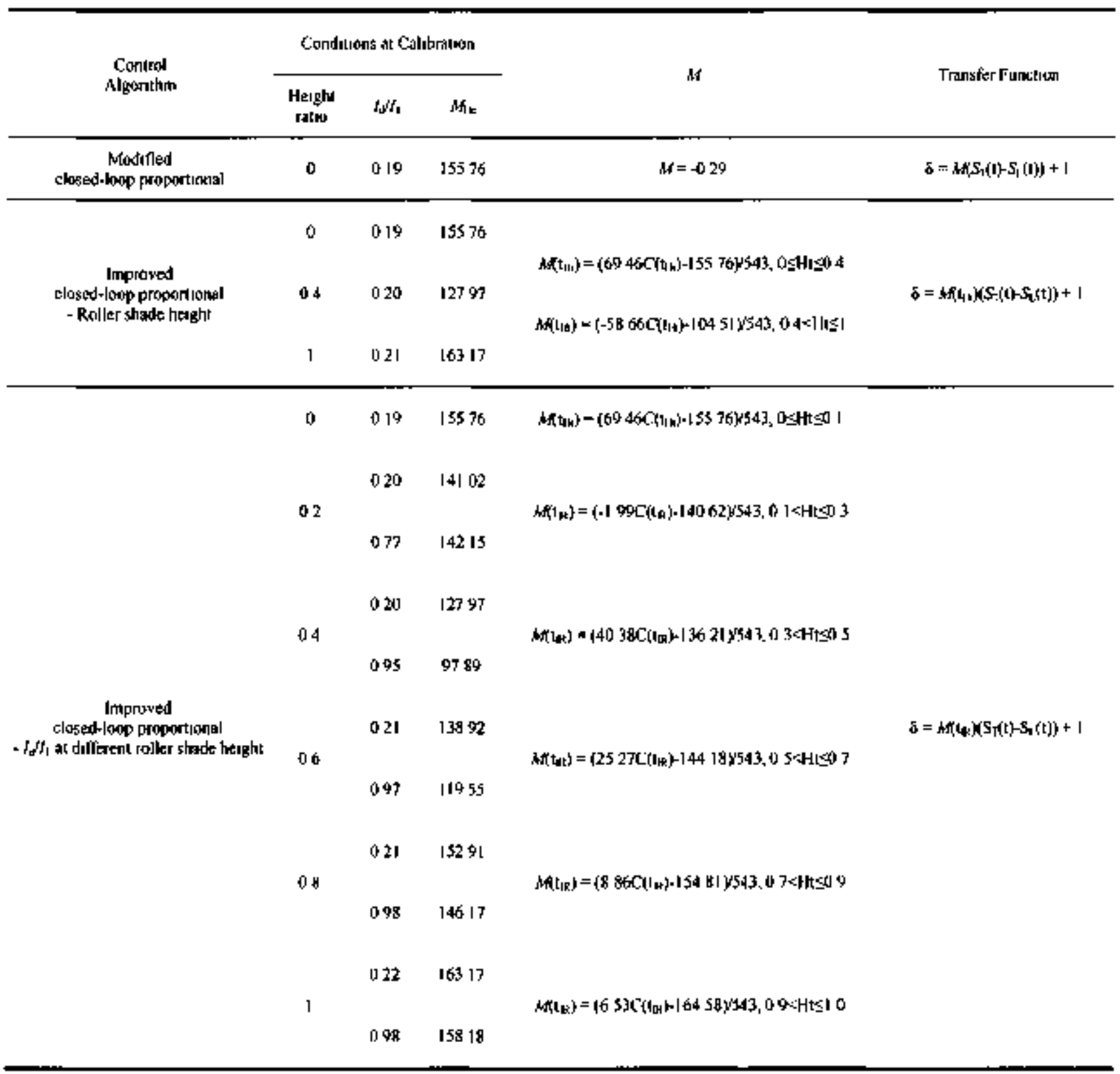

The pertormance of each of the system algotithms was evaluated and then compared using the monitorid dala (Table 4). '] the integlated systems wilh either of the improved closed-loop proportional control algorithons achieved a system performance that wias more accurate than that of the single system with the moditied closedlowp proportional control algorithm. The average maintenance percentages of the targel illuminance for the single daylight responsive dimming systems, the integreated systems using only roller shorde height, and the 
integraled systems using the $f_{\mathrm{d}} t_{\mathrm{T}}$ ratio at different roller shade heights were around $97.1,98.2$, and $98.7 \%$, respectively, and their average discrepancies wete $40.23( \pm 42.40)$ lux, $28.59( \pm 36.86)$ lux, and $24.94( \pm 37.07)$ lux, respecively. The values of the standard deviation on the derived average discrepancies were larger than the average values. The discrepancics were highly skewed when rollet shade height changed (t.g. especially from 0.4 to 0.6 ratio of roller shade hejghi). Although the average maintenance pencentages did not increase significantly, the averoge discrepancies and the average emor lime (mit) under $90 \%$ of torget illuminance per day as an inadequate value decreased significantly in the hoth inlegrated systems.

\section{Table 4}

Comparison of the control algorithms based on the average difference between the predicted and measured workplane illuminance, the mainlenance percentage of target illaminence, and the average time under $90 \%$ of lirgel IIluminance throughoul a day $\{8: 00-18: 00)$.

\begin{tabular}{|c|c|c|c|c|c|c|}
\hline \multirow{2}{*}{ Heins } & \multicolumn{2}{|c|}{ 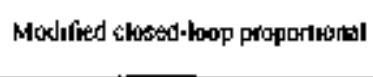 } & \multicolumn{2}{|c|}{$\begin{array}{c}\text { Improwed clased-locop proportional } \\
\text { whlh roller slupde HL }\end{array}$} & \multicolumn{2}{|c|}{  } \\
\hline & Méñn & SI Dev & Menn & SI Dev & Mesn & Si [etr \\
\hline Dillenende (lux) & 4023 & 4240 & 2859 & 3685 & 2494 & $37 \cup 7$ \\
\hline Marmenance (\%) & 9709 & 72 & $98 \eta 2$ & $s 73$ & ו & 513 \\
\hline $\begin{array}{l}\text { Linder 90\%/ Ierger } \\
\text { Illumumance } \\
\text { \{miniday') }\end{array}$ & 6633 & 5321 & $24+1$ & 3035 & 1295 & 1276 \\
\hline
\end{tabular}

\subsection{Canse of inadequate if in each inproved closed-loop propordonal cantrol argorithm}

[nsufficient data under $90 \%$ of the target illuminance wese collected to cxamine causes of inadequate workplane illumitrance in the integrated systems with the improved closed-loop proportional sontrol algorithm. The dala were analyzed based on roller shade height, $f_{d} / t_{T}$ ratio. solar position, and penetration of the photosensor detecling area. The day with the most errors in each month wis selected as the basis on which to determine the cuuses of errors (Fig. 6).

Inlerference by diract surlight in the PS-ceil detecting area was got the main cause of the errors; only $16.5 \%$ of toul errors in one integrated system and $11.4 \%$ in the olher were affected by direct sunlight (data nol shown). There were some pattems of high-frequency for roller shade height, $f_{d} t_{T}$ ratio, and solar position, with both integraled systems showing sinilar results (Fig. 6). Except for the June do data, dhe frequency was high al uround a 0.4 ratio ( $40 \%$ ) of the conirolled Joller shade height lo its maximurn height and the $f_{0} / f_{\mathrm{T}}$ ralio was also high. The errors in the integrated systems using only soller stade height primarily occurred under $-45^{*}$ and over

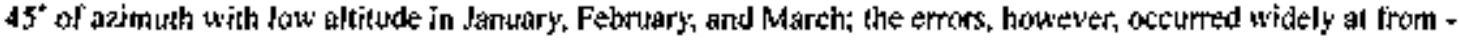
$90^{\circ}$ to $90^{\circ}$ of azimuth after Manch. However, the emors in the integraled systems using the $\delta_{d} / t_{\mathrm{T}}$ ratin at different roller shade heights decreased signilicantly betueen $-45^{\circ}$ and $45^{\circ}$ of azimuch arier March. 

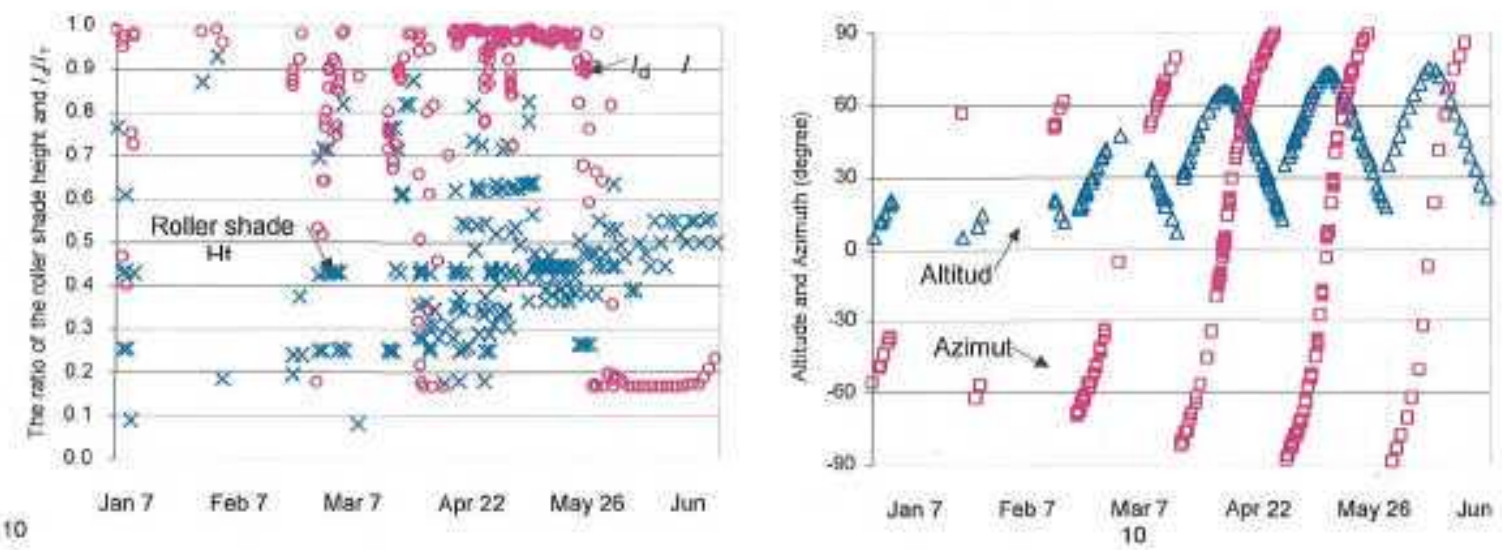

a) Improwed closed-loop proportional whth roller shade height
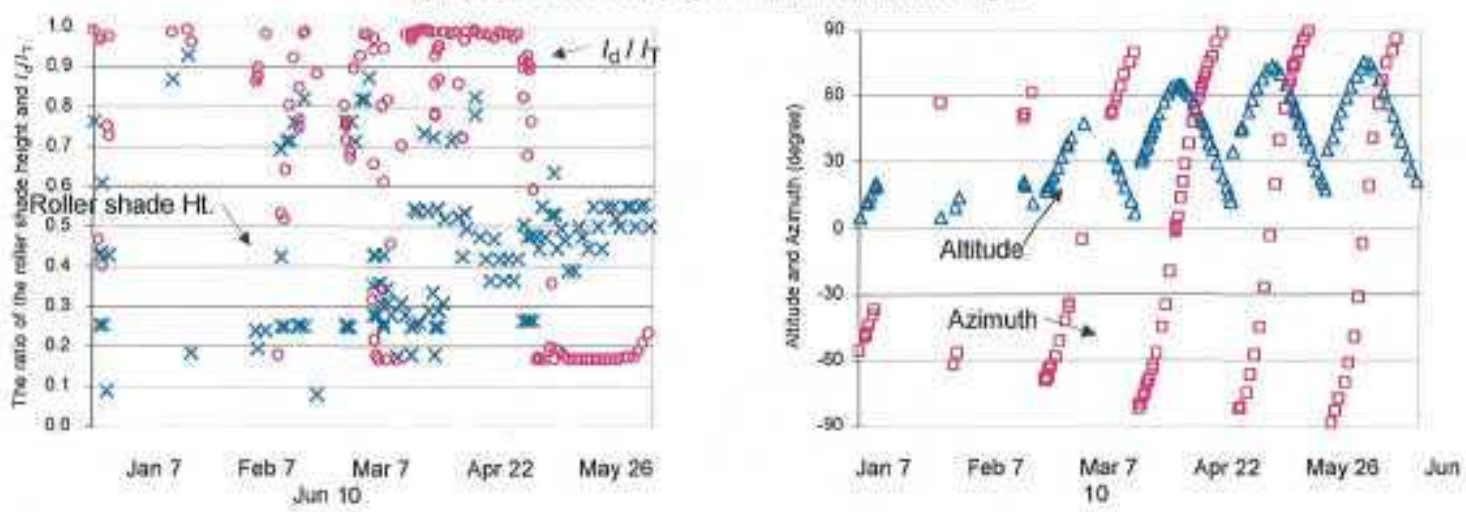

b) Improved closed-loop proportional with $\left(d / f_{7}\right.$ ratio at different roller shade height

Fig, 6. Distribution of errors based on $I_{d} / I_{T}$ ratio, roller shade height, and solar positions.

\subsection{Verification of the results using extra test}

To compare the full-scale testbed and the half-scale testbed results, the fifteen-day data collected during the solstice-to-solstice test period were included in the dataset for analysis. In the dataset, the controlled roller shade height was varied from 0 to around 0,3 of the ratio (the controlled roller shade height to its maximum height) throughout the course of a day. This condition can be compared with the result from the full-scale testbed in Fig. 4 , which is a correlation of varying $M_{\mathrm{D}}$ to roller shade height under 0.4 of the roller shade height ratio.

To examine whether the correlation of the varying $M_{\mathrm{D}}$ to roller shade height is different, the correlation of $M_{\mathrm{D}}(t)$ to the controlled roller shade height from the data monitored in the half-scale testbed was derived and given in Fig. 7, such as in Fig. 4. Unlike the results from the full-scale testbed, this $M_{\mathrm{D}}$ trend gradually increased. The dataset was divided based on 0.13 of the roller shade height, as (1) the trend of the varying $M_{0}$ to the increased roller shade height at $0-0.13$ of roller shade height is flat, and then (2) the trend of $0.13-0.32$ gradually increased. This seems to be the turning point, as 0.4 of the roller shade height (Fig. 4 ) occurred at around 0.1 of the roller shade height. 


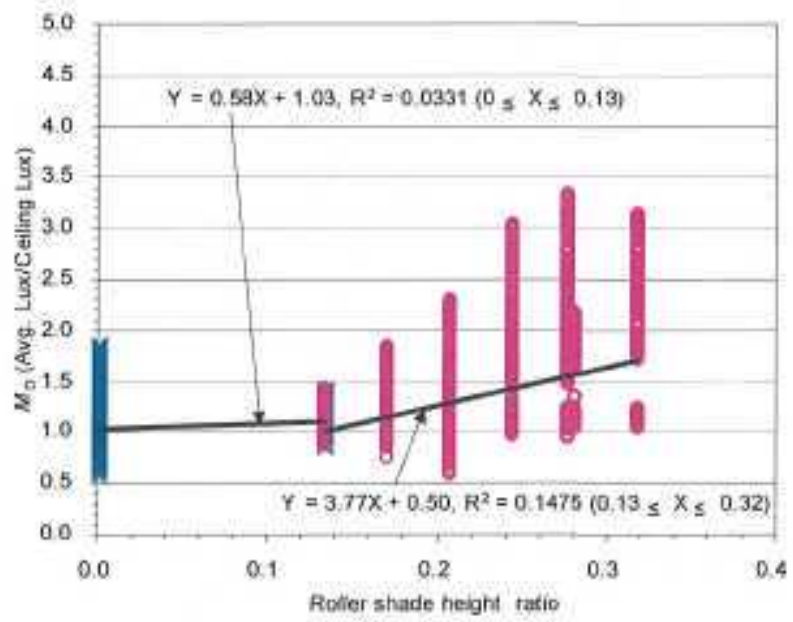

Fig. 7. Linear relationship of $M_{\mathrm{B}}$ to roller shade height in half-scale mock-up.

To examine how different photosensor location and configuration affect the trend of varying $M_{\mathrm{D}}$ to roller shade height, computer simulations using RADIANCE 3.8 for Linux were conducted based on the same location and different photosensor conditions. The simulation results were compared to the results of the full-scale testbed and half-scale testbed.

The conditions of test room size, interior surface reflectances, window transmittance, $60^{\circ}$ photosensor, and shade material were identical to those of the full-scale testbed. And, the conditions of the full-scale testbed location and the $180^{\circ}$ photosensor were identical to those of the half-scale testbed. The simulation conditions are shown in Table 5 and Fig. 8. For reference, the computed $R_{Y}$ and $T_{V}$ for this RADIANCE simulation were calculated using their RGB reflectance or transmittance.

\section{Table 5}

Test room conditions on the location, size, roller shade, interior surface reflectance, and window transmittance for computer simulation.

\begin{tabular}{|c|c|}
\hline Location & Latitude $37^{\prime} 33^{\prime} \mathrm{N}$, longitude 12704 'E, Sevul \\
\hline Test room size & $3.05 \mathrm{~m}$ wide by $4.57 \mathrm{~m}$ deep by $3.35 \mathrm{~m}$ high \\
\hline Roller shade & $3 \%$ openness factor, 6 -step roller shade height for 0.2 interval \\
\hline Interior surface retlectance $\left(R_{y}\right)$ & Ceiling $(0.86)$, wall $(0.85)$, floor $(0.18)$ \\
\hline Window transmittance (Ty) & 0.62 \\
\hline
\end{tabular}






- Illuminance Sensor

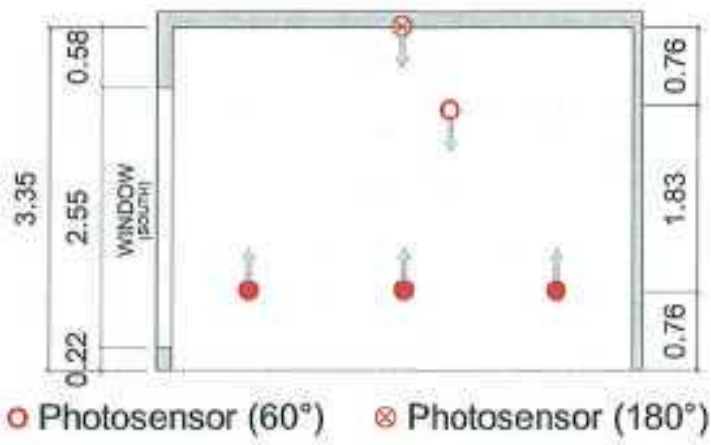

Fig. 8. Calculation point on the photosensor signal and workplane illuminance. Dimensions are given in meters.

Conducted with a variety of roller shade heights under diverse sky conditions ( $+\mathrm{s},-\mathrm{s},-\mathrm{i}$, and $-\mathrm{c}$ for "Gensky" of RADIANCE 3.8 for Linux), the hourly computer simulations took place 9:00 a.m.-18:00 p.m. on Dec 21, Mar 21 , and Jun 21 . Firstly, the trend of the varying $M_{\mathrm{b}}$ to roller shade height under the various sky conditions on the $180^{\circ}$ photosensor located in the middle of the ceiling surface was derived, as shown in Fig. 9. Secondly, the trend on the $60^{\circ}$ photosensor located $2.54 \mathrm{~m}$ above the finished floor was derived, as shown in Fig. 10.

Fig. 9 shows that the turning point occurred at 0.1 of the roller shade height. This result can be compared with the results of Fig. 7 for the half-scale testbed, which shows that the full-scale and half-scale testbeds evinced a similar turning point with regard to the correlation of $M_{0}$ to roller shade height.



Fig, 9. Linear relationship of $M_{\mathrm{D}}$ to roller shade height on the $180^{\circ}$ photosensor.

The trend of the $60^{\circ}$ photosensor (Fig. 10) shows that the lowest value in correlating $M_{\mathrm{D}}$ to roller shade height occurred at 0.3 of the roller shade height. This result can be compared with those for the full-scale testbed (Fig. 4): the full-scale and half-scale testbeds showed a similar turning point in correlating $M_{0}$ to roller shade height. 




Fig. 10. Linear relationship of $M_{\mathrm{D}}$ to roller shade height on the $60^{\circ}$ photosensor.

Therefore, the correlation of $M_{\mathrm{b}}$ to roller shade height shows a trend expressed as a "V" line. To use the improved control algorithm for the integrated systems, the correlation of the varying $M_{\mathrm{D}}$ to roller shade height should be separated in two ranges in order to achieve a linear relationship. The turning point, critical for dividing the two roller shade height ranges, is significantly affected by both the configuration and the position of the photosensor.

\section{Discussion}

When valid $M_{\mathrm{D}}$ data were separated at a 0.4 ratio of the roller shade height, the varying $M_{\mathrm{D}}(\mathrm{t})$ was shown as having a linear relationship. The roller shade height was cycled at 0.2 ratio intervals of the controlled height to maximum height. The 0.4 ratio of the roller shade height as a turning point from the results of full-scale testbed could be changed more or less than 0.4 ratio when the roller shade was cycled at intervals of less than a 0.2 ratio of the roller shade height.

The reliability of PS-ceil is decreased when direct sunlight interfered in the PS-ceil detecting area. The reliability of the derived linear fit of $I_{d} / I_{\mathrm{T}}$ to the varying $M_{D}$ on the PS-ceil improved when the interfered data were excluded. Therefore, to improve the accuracy of the integrated systems, which can control roller shade height for available daylight in a space as well as artificial lighting output for energy savings, direct sunlight into the photosensor-detecting area should be blocked using roller shade system for the reliability of PS-ceil. The photosensor detecting area should be determined with the permitted distance of direct sunlight from window, such as $1.25 \mathrm{~m}$ in Fig. 3, because the direct sunlight can lead discom fort glare as well as electric lighting energy savings.

The performance of the integrated systems with the two improved closed-loop proportional control algorithms was exaluated. This performance was compared with that of the daylight responsive dimming systems with the modified closed-loop proportional control algorithm, that is, the algorithm that is currently in general use. Although the modified closed-loop proportional control algorithm uses the fixed $M$, the improved closed-loop proportional control algorithm uses the changed $M$ to respond to varying roller shade heights and $I_{d} I_{T}$ ratios. The performance comparison showed that the average maintenance percent to the target illuminance for both the improved closed-loop proportional control algorithms was slightly higher than that of the modified closed-loop proportional control algorithm, but the average error time under $90 \%$ of the target illuminance significantly decreased for the former. As in actual applications, the minimum number of calibrations was assumed to evaluate the performance of the improved closed-loop proportional control algorithm. It can be assumed that the more sophisticated calibration (more than two calibrations) in each subdivided condition is likely to achieve further performance improvements.

Inadequate workplane illuminance errors in the improved closed-loop proportional control algorithm occurred frequently when the sun leaned to the east and west on the plane; these errors also occurred frequently when the $I_{i l} / I_{T}$ ratio was high. It can be assumed that if direct sunlight were controlled in the azimuth so as to be redirected 
through a window into a space less than $45^{\circ}$ (absolute value) of the sun's arimuth angle using an exterior shading system, such as a vertical shade, then the number of ercors would dactedse.

To validatc the rcsult from full-scale testbod, the datasel monitorod in the half-5cale testbed was analyzed based on the correlation of $M_{0}$ to the roller shade height In this analysis, the turning point of 0.4 roller shade teight ratin in Fig. 4 shifted toward a lower roller shade height of around 0 . I rollet shade height ratio. I'he computer simulation resulis validated the correlation trend of the $M_{0}$ to the roller shade height for the full- and half-scale lesibeds. It was found that the pholosensor configuration and position affect the turning point level of the correlation of the $M_{0}$ to the roller shade height. Therefore, the improved control algorithm for the integrated sygtems can be adopted in a 5 ace with automated roller shade systems and daylight responsive dimming systems.

\section{Cunclusions}

The fixed $M_{\mathrm{v}}$ to calculate $H$ is used in current control algorithm of daylight responsiy dimming sysiems, and this causes inadequate workplane illuminance due to the variation of $w_{0}$ actoss a day. To render the performance of daylight responsive dimming system more accurate, a field-test was conducted for this study:

To integraie automaled roller shade systenıs and daylight responsive dimming systems, the effocts of roller shade height and $f_{\mathrm{d}} / f_{\mathrm{T}}$ ratio on $M_{\mathrm{D}}$ were investigated using the data otitained from the test room with cycled rolker shade heighıs (6 steps for a 5 -min interval). Varying $M_{\mathrm{D}}$ was adopted into the control algorithm for integrated systems when the lormer was directly proportional to independent variables such as roller shade hejght and $t_{V} / t_{\mathrm{T}}$ ralio at each điffęręnt roller shade height.

The integrated system performance was relatiwcly compared to the single system perlormance in this study. To compare the two improved closed-loop proportional control algorithms for the integraled systems and the current closed-loop control algorithm for daylight responsive dimming systems as a single system, three monilored dala, the average maintenance percentage, the average discrepancies, and the average time under $90 \%$ based on the target illuminante, were calculated and sompared for each algorithm. Bolh improved closed-low proportional tontral algorithms for each of the integrated systems were significantly improved when compared to the current closed-loop proportional contcol algorithm.

To improve the performance accuracy of daylight responsive dimming systems, jntiormalion regarding roller shade height should be included in the control soltware for the inprovement of the clased-loop proportional conirol algorithm. Through an integration of software of daylight rcsponsiye dimming systems and automated roller shade systems, the improyed closed-loop proportional control algorithm could be used in conventional daylight responsive dimming systems with no added components. However, also needed are inlegrated syslems with the impoved closed-loos proportional contol algorithm using the $t_{d} / t_{\tau}$ ralio for difterent roller shade heights that would isclude an additional component. That is, an exlerior global irradiance sensor ls tequired to calculate the $I_{d} / t_{T}$ ratio. Although the addition of an imadiance sensor to this integratod system rieans that the inilial costs are higher, the sysicm accuracy is significantly improved based on this study. Therefore, the improved system accurasy could be inșumental in accelerating markel adoption of daylight responsive dimming systems.

\section{Acknowledgmęnts}

We would like to acknowiedge and thank R.D Clear for statistical data extraction. We would like also to acknowledge and thank K. ए (:lear, S.E. Selkowitz. D.I. [Jißartolomeo and K. Konis for their conlributions lo the field test at the Window's Testbed Facility, Lawrence Berkeley National Laboratory.

This work was also supported by Samsung Corporation, hy the Assistant Secretary for Energy Efficiency and Renewable Energy: Oftice of Building Technology. State and Community Programs, Oflice of Building Research and Slandards of the UIS. Department of rinergy undel Contract Na. Ut:-ACU2-1356H 1 123I, and by the Califomia Energy Commission through its Public interest Energy Research (PIER) Frogram. And, the maill author was tundest by $2^{\text {*d }}$ Brain Konsa 21 project. 


\section{References}

[1] Lee, E.S.. DiBartolomeo, D.L., Selkowiliz. S.E., 1998. The Effect of Yenetian Blinds on Daylight Pholuelectric Contro] Performance. Journal of the Illuminating Engineering Society 28, 3-23.

[2] Rubinstein, F., Jennings, J. Avery, D. Blanc, S., 1999. F'scliminary Resuls from an Adyanecd Lighting Controls Testhed. Journal of the Jlluminaling Engineering Society 28, 130- 14 ].

(3) Choi, A., Sung. M., 2000. Development of a Daylight Responsive Dimming System and Prefiminary Evaluation of Sysiem Performance. Building and Enviconment 35, 663-676.

[4] Lec, E.S., Sc]kowitz, S.E., 2006. The New York Times Headquarters Daylighting Moskup; Monitored Performance of the Daylighting Control System. Energy and Buildings 38. 914-924.

[5] Roche, I., 20012. Summertime Performance of an Aulomated Lighting and Blinds Control System. Lighting Reseurch and Technology 34, 11-27.

[6] Kay]e, B., Papamichael, K., Pistochini, T, 2009. Improvisd Daylighting Conitals through Dual Loop Sensing. Oral session presented al the IESNA Annual Conference Scattle, Wh.

[7] Nistrick, R.G, Chen, C., Bierman, A., Feltș, D., 2000. A Comparison of Photosensor-Controlled Electronic Dimming Systens in a Small Office. Journal of the Illuminating Fngineering Society 28, 39-73.

[8] Rubinstein, F., 1984. Pholok]ectric Control of Equi-flluminalion Lighting Sys[tms. Energy and Buildings 6. I $41-150$.

[9] Rubinstein, F., Ward, G, Verderter, R., 1989. Improving the Performance of Photoelectriçally Controlled Lighting Systems. Joumal of the Illuminating Enginetering Sociely 18, 70-94,

[I0| Ranasinghe, S., Mistrick, R.G. 2003. A Sudy of Photosensor Configuration and Performance in a Dyalighled Clasșroom Space. Jourjal of the Illumiuating Engineering Society 32, 3-20.

[1 ] Choi, A, Song, K, Kim, Y, 20015. The Characteristics of Photosenoors and Electronic Dinming Ballasts in Daylight Responsive Dimming Sysıms. Building and Envitonment 40, 39-50.

[12] Kim, S., Kim, J., 200r. The Impact of Daylight Flactuation or a Daylight Dimming Control System in a \$mall Office. Energy and Buildings $39,935-944$.

[13] Chui, A., Mistrick, R.G., 1997. On the Prediction of Energy Savings for a Daylight Dimming System. Joumal of the llluminaling Engincering Socicty 26, 77-90.

[I4] Kim, S., Mistrick, R.G., 200I. Recommended Daylight Conditions lor Photosensor 5ystem Calibration in a Small office. Journal of the Illuminating Engineering Sociey 30, I76- I88.

[IS] Choi. A., Mistrick, R.G., 1998. Analysis of Daylight Responsive Dimming System Pelformance. Building and Enyitonment 34, $231-243$.

[16] NYSERDA, 2005. Daylighting the New York Times Headquarters Building. Final Report 06-05, 16.

[17] Lex, E.S. DiBartolomeo, D.L.., Klems, J.H., Konis, K., Clear, R.D., Yazdanian, M., et al., 2009. Field measurements of innovative indoor shading systems in a ful|-scale office testbed. ASHRAE transactions I15.

[18] Park, B., Choi, A., 2009. A Study on the Improvement of Accuracy of Daylight Responsive Dimming Systems' Algorithm. 2nd Chint, Japan, and Korea Lighting Symposium Sapporo.

[I] Erbs, D.G, Klein, S.A., Duftè, J.A., 1982. Estimation of the Diffuse Radiation Fraction for Hourly, Daily and Monthly-Average Gilohal Radiation. Solar Energy 28, 29.3-3U2. 